\title{
Association of newborn diseases with weight/length ratio and the adequacy of weight for gestational age
}

\author{
Associação de afecções neonatais com a relação peso/comprimento e a adequação de peso \\ para idade gestacional
}

José Ricardo Dias Bertagnon ${ }^{1}$, Marcos da Cruz Rocha ${ }^{2}$, Gabriela Alba Kuraim², Rosângela Guidara², Neil Ferreira Novo ${ }^{3}$

\begin{abstract}
Objective: To compare the frequencies of newborn diseases in those newborns classified according to a weight/length rate and those classified by the adequacy weight for gestational age. Methods: A retrospective cross-sectional study by record assessment was carried out enclosing all the live newborns at Hospital Geral do Grajaú, from September to December, 2009 ( $n=577)$ classified according to the rate weight/length and also to the adequacy weight for gestational age. The 10 and 90 percentiles of the weight/length distribution, now designated as "indices" were calculated leading to the following classification: low index, for newborns below $54.8 \mathrm{~g} / \mathrm{cm}$; high index, for those over $75.8 \mathrm{~g} / \mathrm{cm}$; and average index, for the remaining newborns. According to the adequacy weight for gestational age the newborns were designated as pre-term for gestational age; term small for gestational age; appropriate term and large term. In this sample there were no small and large pre-term or post-term newborns. Major diseases were related to the index and adequacy extracts by the $\chi^{2}$ test for a contingency table. Results: A significant association was found among low index, pre-term for gestational age newborns and term small for gestational age; between average index and appropriate for gestational age term newborns; and high index with large term appropriate for gestational age newborns $(p<0.001)$. Hypoglycemia $(3.4 \%)$ was associated to both low and high indices, to appropriate for gestational age preterm newborns and to small for gestational age term newborns. Sepsis (3.1\%) was associated to both low index and pre-term appropriate for gestational age newborns. The respiratory distress syndrome (1.3\%) was associated to low index and pre-term appropriate for gestational age newborns. Other respiratory distress syndromes $(3.8 \%)$ were associated to low and high indices but not to the adequacy for gestational age classification. Jaundice (14.9\%) was not associated to the studied classifications. Perinatal asphyxia $(12.6 \%)$ was associated to low index and pre-term newborns.
\end{abstract}

Conclusion: The weight/length index may represent a contribution to the newborn risk classification being similar to that of the weight for gestational age adequacy, for the studied diseases.

Keywords: Gestational age; Infant, newborn; Fetal weight; Birthweight

\section{RESUMO}

Objetivo: Verificar qual a frequência de afecções em cada extrato de recém-nascidos classificados segundo relação peso/comprimento e comparar com essas frequências nos extratos da classificação segundo a adequação do peso para a idade gestacional. Métodos: Estudo retrospectivo transversal por avaliação de prontuário de todos os recém-nascidos vivos no Hospital Geral do Grajaú, de Setembro a Dezembro de 2009 ( $n=577$ ), classificados segundo a relação peso/comprimento e também pela adequação peso para idade gestacional. Foram calculados os percentis 10 e 90 da distribuição da relação peso/comprimento, denominada "índice", definindo-se como índice pequeno os recém-nascidos abaixo de $54,8 \mathrm{~g} / \mathrm{cm}$, índice grande os acima de $75,8 \mathrm{~g} / \mathrm{cm}$ e índice médio o restante. De acordo com a adequação do peso para a idade gestacional os recém-nascidos foram designados como pré-termo apropriado para idade gestacional, termo pequeno para idade gestacional, termo apropriado para idade gestacional e termo grande para idade gestacional. Nessa amostra não foram encontrados recém-nascidos pré-termo grande para idade gestacional, pré-termo pequeno para idade gestacional e nem pós-termo. As principais afecções dos recém-nascidos foram relacionadas aos extratos dos índices e das adequações pelo método do $\chi^{2}$ para tabela de contingência. Resultados: Houve associação significante entre índice pequeno com pré-termos apropriados e com termo pequeno; índice médio

\footnotetext{
Study carried out at Hospital Geral do Grajaú Professor Liberato John Alphonse Di Dio - Sao Paulo (SP), Brazil.

1 Faculdade de Medicina, Universidade de Santo Amaro - UNISA, Sao Paulo (SP), Brazil.

${ }^{2}$ Hospital Geral do Grajaú Professor Liberato John Alphonse Di Dio - Sao Paulo (SP), Brazil.

${ }^{3}$ Department of Public Health, Universidade de Santo Amaro - UNISA, Sao Paulo (SP) Brazil.

Correspondence: José Ricardo Dias Bertagnon - Rua Francisco Romeiro Sobrinho, 171 - Chácara Santo Antonio - CEP 04710-180 - Sao Paulo (SP), Brazil - Tel.: (11) 5181-5330 - E-mail: joserimed@uol.com.br

Received on: Apr 30, 2011 - Accepted on: Aug 11, 2011

Conflict of interest: none.
} 
com termo apropriado para a idade gestacional e índice grande com termos grandes para idade gestacional $(p<0,001)$. A hipoglicemia $(3,4 \%)$ se associou tanto ao índice pequeno como ao índice grande, a pré-termos apropriados e a termo pequenos para a idade gestacional. A sepse $(3,1 \%)$ associou-se a índice pequeno e a prétermo.A síndrome do desconforto respiratório $(1,3 \%)$, associou-se com índice pequeno e pré-termos apropriados. Outros desconfortos respiratórios $(3,8 \%)$ mostraram associação com índice pequeno e índice grande, mas não com a adequação peso para idade gestacional.A icterícia (14,9\%) não mostrou associação com qualquer das classificações estudadas. A asfixia (12,6\%) associouse ao índice pequeno e aos recém-nascidos pré-termo. Conclusão: 0 índice peso/comprimento pode contribuir para a classificação de risco para recém-nascido de maneira semelhante à da adequação peso para idade gestacional, para as afecções estudadas.

Descritores: Idade gestacional; Recém-nascido; Peso fetal; Peso ao nascer

\section{INTRODUCTION}

The classification of newborns (NB) by the weight/ length ratio denominated index allows identifying NB at risk for several diseases. Newborns with indices below the $10^{\text {th }}$ percentile have a greater frequency of diseases, such as neonatal asphyxia, respiratory distress syndrome, metabolic disorders, severe hyperbilirubinemia, sepsis, congenital pneumonia, among other perinatal disorders $^{(1)}$. In spite of the fact that the calculation of the index does not consider the gestational age (GA) but only the weight and length at birth, it is noted that those NB identified as having a low index present a greater frequency of diseases specific of preterm (PT) infants and of small-for-gestational-age (SGA) infants, and the NB with high indices have a greater frequency of diseases that affect large-for-gestational-age (LGA) neonates ${ }^{(1)}$.

The association between birth length and GA is more intense and shows less variation than the relation between birth weight and $\mathrm{GA}^{(1-4)}$. On the other hand, neonates with lower weight/length ratio indices reflect NB with smaller fat deposits, and can be considered thin $\mathrm{NB}^{(1,5-7)}$. Infants with higher indices reflect greater fat deposits $^{(1)}$. However, SGA NB correspond to children whose weight is less than what would be expected for that GA, without considering their length ${ }^{(8)}$, which will classify a thin NB in the same category as the genetically small NB, and this latter might have a normal or even high proportion of the weight/length ratio $^{(1)}$. Moreover, the NB with a low index includes the PT NB and the SGA NB in the same category, since the fat deposits and greater muscle mass are produced more rapidly at the end of gestation, making these NB, who did not complete their ideal gestational time, small in the weight/length ratio ${ }^{(1)}$.

\section{OBJECTIVE}

To verify if the occurrence of diseases in each classification of NB per weight/length ratio index is comparable to the frequencies according to the adequacy of weight for gestational age in a population seen at a hospital in the southern region of the city of Sao Paulo.

\section{METHODS}

A cross-sectional retrospective study by evaluation of medical charts of all live NB who were discharged from September to December 2009 at Hospital Geral do Grajaú (HGG), which were considered as inclusion criteria. The exclusion criteria were congenital malformations and twin neonates.

According to a first classification criterion, the weight of the NB, measured in grams right after birth, was divided by its length in centimeters and the weight/ length ratio was called "index." With the distribution of the indices, the $10^{\text {th }}$ and $90^{\text {th }}$ percentiles were calculated. The $10^{\text {th }}$ percentile was identified as $54.8 \mathrm{~g} / \mathrm{cm}$. Newborns with indices below this value were classified as having a low index. The $90^{\text {th }}$ percentil value was $75.8 \mathrm{~g} / \mathrm{cm}$ and the NB with values equal to or greater than this were classified as having a high index. All the others were considered as having a medium index. The values found were compared to those of the distribution of the index for another population ${ }^{(1)}$ using Student's $t$ test for two independent samples for validation purposes.

The second criterion of NB classification was based on the weight adequacy for gestational age. According to the distribution of birth weight for each GA, in complete weeks as calculated by the Capurro method ${ }^{(9)}$, an intrauterine growth curve was constructed for this population. The weights that occupied the $10^{\text {th }}$ and $90^{\text {th }}$ percentiles of the distribution for each GA were verified and NB were classified as small (SGA), appropriate (AGA), or large for the GA (LGA); they were also classified as preterm (PT), full term (FT), or post-term (postT), depending on a GA of less than 37 weeks or 42 weeks or more. An Excel table was also created with birth weight, length, GA, and the indices.

The association between the indices with the adequacy weight for GA was calculated using the qui square test, as well as the association between these two independent classifications with selected diseases frequently found in the NB (hypoglycemia, sepsis, perinatal asphyxia, respiratory distress syndrome, other respiratory diseases, and neonatal jaundice) were also calculated by the qui square test for a contingency table. Hypoglycemia was considered when digital glycemia values were lower than $40 \mathrm{mg} \%$. Sepsis was defined when there was clinical and laboratorial evidence; 
anoxia, when the Apgar score during the first minute of life was $<7$. The respiratory distress syndrome (RDS) was diagnosed by the clinical picture associated to radiological findings. Other respiratory diseases included congenital pneumonia, transient tachypnea, meconium aspiration syndrome, and adaptive respiratory disease, and these were grouped by frequency in this population. Jaundice was diagnosed in the presence of a clinical picture with no etiological concern.

\section{RESULTS}

The sample comprised 577 NB during the period of the study. There were no NB with congenital malformations or twins.

Table 1 shows the values of the weight/length indices for the $10^{\text {th }}$ and $90^{\text {th }}$ percentiles, and the distribution values of this index (normal distribution); they are compared to the same parameters of distribution of the index in another defined population ${ }^{(1)}$.

Table 1. Values of weight/height indices for the $10^{\text {th }}$ and $90^{\text {th }}$ percentiles in the population at the Hospital Geral do Grajaú and the population defined from another institution

\begin{tabular}{lccccc}
\hline Institution & $\mathbf{n}$ & $\begin{array}{c}\text { Weight/height } \\
\text { index 10 } \\
\text { percentile (LI) }\end{array}$ & $\begin{array}{c}\text { Weight/height } \\
\text { index 90 } \\
\text { percentile (HI) }\end{array}$ & Mean & $\begin{array}{c}\text { Standard } \\
\text { deviation } \\
( \pm)\end{array}$ \\
\hline HGG & 577 & 54.8 & 75.8 & 64.67 & 7.65 \\
Other & 4634 & 56.3 & 74.2 & 65.11 & 7.83 \\
\hline
\end{tabular}

$t=1.26 ; p=0.276$.

HGG: Hospital Geral do Grajaú

Ll: low index

HI: high index

No significant difference was noted between the distribution of the index at HGG and that of another population studied at another institution.

Table 2 shows the relation between the two classifications.

Table 2. Relation between the classification of newborns by the weight/height index and range of weight for gestational age

\begin{tabular}{lcccccccccc}
\hline \multirow{2}{*}{ Classification } & \multicolumn{2}{c}{ PT AGA } & \multicolumn{2}{c}{ T SGA } & \multicolumn{2}{c}{ T AGA } & \multicolumn{2}{c}{ T LGA } & \multicolumn{2}{c}{ Total } \\
\cline { 2 - 11 } & $\mathbf{n}$ & $\mathbf{R F} \%$ & $\mathbf{n}$ & $\mathbf{R F} \%$ & $\mathbf{n}$ & $\mathbf{R F} \%$ & $\mathbf{n}$ & $\mathbf{R F} \%$ & $\mathbf{n}$ & $\mathbf{R F} \%$ \\
\hline $\mathrm{LI}$ & 30 & 44.1 & 23 & 33.8 & 15 & 22.1 & 0 & 0.0 & 68 & 10.1 \\
$\mathrm{Ml}$ & 5 & 11.0 & 33 & 72.0 & 394 & 86.9 & 21 & 4.8 & 454 & 80.2 \\
$\mathrm{HI}$ & 0 & 0.0 & 0 & 0.0 & 18 & 32.7 & 37 & 61.8 & 55 & 9.75 \\
\hline Total & 35 & 6.0 & 56 & 9.7 & 427 & 74.0 & 59 & 10.2 & 577 & 100 \\
\hline
\end{tabular}

$\chi^{2}=479.0 ; p<0.0001$

RF: relative frequency (percentage)

LI: low index; MI: medium index; HI: high index; PT AGA: preterm appropriate for gestational age; FT SGA: full term small for gestational age; FT AGA: full term appropriate for gestational age; FT LGA: full term large for gestational age.

There was a significant association between low index and PT AGA and with FT SGA infants; medium index with FT AGA; and high index with FT LGA babies.
Table 3 shows the frequency of diseases in different indices levels.

Table 3. Weight/height index and association with diseases

\begin{tabular}{|c|c|c|c|c|c|c|c|c|c|c|c|c|c|c|}
\hline \multirow[t]{2}{*}{ Index } & \multicolumn{2}{|c|}{ Hypogl. } & \multicolumn{2}{|c|}{ Sepsis } & \multicolumn{2}{|c|}{ RDS } & \multicolumn{2}{|c|}{ Jaundice } & \multicolumn{2}{|c|}{$\begin{array}{c}\text { Other } \\
\text { Resp. } \\
\text { Distress }\end{array}$} & \multicolumn{2}{|c|}{ Asphyxia } & \multicolumn{2}{|c|}{ Total } \\
\hline & $\mathbf{n}$ & RF\% & $\mathbf{n}$ & RF\% & $\mathbf{n}$ & RF\% & $\mathbf{n}$ & RF\% & $\mathbf{n}$ & RF\% & $\mathbf{n}$ & RF\% & $\mathbf{n}$ & RF\% \\
\hline LI & 6 & 8.8 & 13 & 19.1 & 7 & 10.3 & 8 & 14.0 & 7 & 10.2 & 14 & 20.6 & 68 & 100 \\
\hline $\mathrm{Ml}$ & 9 & 2.0 & 1 & 0.2 & 1 & 0.22 & 68 & 16.0 & 12 & 2.6 & 49 & 10.8 & 454 & 100 \\
\hline $\mathrm{HI}$ & 5 & 5.4 & 2 & 3.6 & 0 & 0.0 & 10 & 18.2 & 3 & 5.4 & 10 & 18.2 & 55 & 100 \\
\hline Total & 20 & 3.1 & 16 & 2.7 & 8 & 1.3 & 86 & 15.2 & 22 & 3.8 & 73 & 12.6 & 577 & 100 \\
\hline$x^{2}$ & & 3.97 & & 8.34 & & 4.66 & & 0.99 & & 9.85 & & 0.77 & & \\
\hline$p$-value & & 0009 & $<0$ & .0001 & $<0$ & .0001 & & 0.6 & & .007 & & 0.03 & & \\
\hline
\end{tabular}

RF: relative frequency (percentage)

LI: low index; Ml: medium index; HI: high index; Hypogl: hypoglycemia; RDS: respiratory distress syndrome; Other Resp. Distress: other respiratory distress conditions.

Hypoglycemia ( $3.1 \%$ of the cases) was associated with both low and high indices. Sepsis $(2.7 \%$ of the cases) was associated with the low indexI. RDS (1.3\% of cases) was associated with the low index. Jaundice $(15.2 \%$ of the cases) was not associated with any index. The other respiratory diseases were associated with both low and high indices; and asphyxia with low index.

Table 4 shows the adequacy weight for GA and its association with selected neonatal diseases.

Table 4. Range of weight for gestational age and association with diseases

\begin{tabular}{|c|c|c|c|c|c|c|c|c|c|c|c|c|c|c|}
\hline \multirow[t]{2}{*}{ Range } & \multicolumn{2}{|c|}{ Hypoglyc } & \multicolumn{2}{|c|}{ Sepsis } & \multicolumn{2}{|c|}{ RDS } & \multicolumn{2}{|c|}{ Jaundice } & \multicolumn{2}{|c|}{$\begin{array}{c}\text { Other } \\
\text { Resp. } \\
\text { Distress }\end{array}$} & \multicolumn{2}{|c|}{ Asphyxia } & \multicolumn{2}{|c|}{ Total } \\
\hline & $\mathbf{n}$ & RF\% & $\mathbf{n}$ & RF\% & $\mathbf{n}$ & RF\% & $\mathbf{n}$ & RF\% & $\mathbf{n}$ & RF\% & $\mathbf{n}$ & RF\% & $\mathbf{n}$ & RF\% \\
\hline PT AGA & 6 & 17.1 & 12 & 34.2 & 8 & 22.8 & 10 & 28.5 & 4 & 11.4 & 14 & 40.0 & 35 & 100 \\
\hline FT SGA & 7 & 12.5 & 3 & 3.6 & 0 & 0.0 & 9 & 16.1 & 2 & 3.6 & 5 & 8.9 & 56 & 100 \\
\hline $\mathrm{FTAGA}$ & 3 & 0.7 & 1 & 0.2 & 0 & 0.0 & 57 & 13.3 & 14 & 3.3 & 46 & 10.8 & 427 & 100 \\
\hline FI LGA & 4 & 6.8 & 1 & 1.7 & 0.0 & 0.0 & 10 & 17.2 & 2 & 3.4 & 8 & 13.7 & 59 & 100 \\
\hline Total & 20 & 3.4 & 18 & 3.1 & 8 & 1.3 & 86 & 14.9 & 22 & 3.8 & 73 & 12.6 & 577 & 100 \\
\hline$\chi^{2}$ & \multicolumn{2}{|c|}{36.5} & \multicolumn{2}{|c|}{139.5} & \multicolumn{2}{|c|}{125.6} & \multicolumn{2}{|c|}{6.24} & \multicolumn{2}{|c|}{5.9} & \multicolumn{2}{|c|}{25.8} & & \\
\hline$p$ value & \multicolumn{2}{|c|}{$<0.0001$} & \multicolumn{2}{|c|}{$<0.0001$} & \multicolumn{2}{|c|}{$<0.0001$} & \multicolumn{2}{|c|}{0.1} & \multicolumn{2}{|c|}{0.11} & \multicolumn{2}{|c|}{$<0.001$} & & \\
\hline
\end{tabular}

RF: relative frequency (percentage)

LI: low index; MI: medium index; HI: high index; PT AGA: preterm appropriate for gestational age; FT SGA: full term small for gestational age; FT AGA: full term appropriate for gestational age; FT LGA: full term large for gestational age. Hypogl: hypoglycemia; RDS: respiratory distress syndrome; Other Resp. Distress: other respiratory distresses.

According to the adequacy weight for GA, it was noted that hypoglycemia was associated with PT AGA, FT SGA, and FT LGA. Sepsis was associated with PT AGA. RDS was associated with PT AGA. Jaundice, although more frequent in PT AGA, showed no association. Other respiratory diseases also showed no association.

Table 5 shows the association between the weight/ length index and the adequacy weight for GA with selected neonatal diseases. 
Table 5. Weight/height index and range of weight for gestational age and association with selected diseases

\begin{tabular}{lcccccc}
\hline Disease & $\mathbf{n}$ & $\%$ & $\begin{array}{c}\text { Index/ } \\
\text { disease } \\
\left(\chi^{2}\right)\end{array}$ & $\mathbf{p}$ value & $\begin{array}{c}\text { Range/ } \\
\text { disease } \\
\left(\chi^{2}\right)\end{array}$ & p value \\
\hline Hypoglycemia & 20 & 3.4 & 13.97 & 0.0009 & 36.5 & $<0.0001$ \\
Sepsis & 18 & 3.1 & 78.34 & 0.0001 & 139.5 & $<0.0001$ \\
RDS & 8 & 1.3 & 44.66 & 0.0001 & 125.6 & $<0.0001$ \\
Jaundice & 86 & 14.9 & 0.99 & 0.6 & 6.24 & $<0.1$ \\
Other Resp. Distress & 22 & 3.8 & 9.85 & 0.007 & 5.9 & 0.1 \\
Asphyxia & 73 & 12.6 & 6.77 & 0.03 & 25.8 & 0.001 \\
\hline
\end{tabular}

RDS: respiratory distress syndrome; Other Resp. Distress: other respiratory distress conditions.

It was also noted that the diseases associated with the indices and with the adequacy weight for GA were more intense in the index classification. The low index included PT as well as FT SGA newborns, which are the most closely related to diseases.

\section{DISCUSSION}

The comparison between the data of the study population with those of another population, despite showing diverse characteristics, showed no significant differences in the $10^{\text {th }}$ and $90^{\text {th }}$ percentiles of the weight/ length index, suggesting that the index may be applied to classify NB in any population.

An association was identified between the two studied classifications, which have birth weight in common, one using the weight/length ratio and the other the adequacy weight for GA. The variables weight and length show an almost linear relation, enabling predictions of weight by the value of length and vice-versa ${ }^{(1)}$. On the other hand, the distribution of length for GA is similar to that of weight for GA, but its correlation coefficient is more intense $\mathrm{e}^{(2)}$.

The most well-known intrauterine growth curves use the variables weight and $\mathrm{GA}^{(10)}$. It has been well established that these curves are able to discriminate NB in levels of risk for specific diseases, but they depend on the GA, which is not always possible to exactly ascertain due to the occurrence of irregularities in the menstrual cycle, individual variations, bleeding at the beginning of gestation, or lack of observation and forgetting dates ${ }^{(11)}$.

In the present study, the NB were classified as per weight adequacy for GA in the sample utilized, according to the specific curve constructed for this population. No standard curve was used, in order to avoid possible errors resulting from the use of an intrauterine growth curves that could classify these NB inadequately ${ }^{(10)}$. The fact of not having found PT SGB or PT LGA neonates probably was because of the sample small size. Theoretically, it could be expected that $10 \%$ of the PT NB would be SGA and 10\% would be LGA. Therefore, among the preterm NB three or four should have been SGA and LGA. This did not happen, which was likely due to random causes. Post-term newborns were not identified, since as they are frequently considered highrisk $\mathrm{NB}$, delivery is resolved before prolonged gestation occurs.

The weight/length index below the $10^{\text {th }}$ percentile also identified NB with less muscle mass and fat, encompassing the PT NB, but also the FT SGA infants, corroborating the findings of the literature ${ }^{(1)}$.

The perinatal diseases selected for the present study were similar to those verified for the population of HGG, as per prior publications ${ }^{(12,13)}$, and most of them being associated with low GA.

The association between hypoglycemia and low index may be explained by the very genesis of the index: the NB with a low index is characterized by less corporal deposits, and consequently, a lower supply of glucose. The association of this condition with the PT AGA NB is explained by the smaller glucose deposits that these babies due to less time of gestation, a lower capacity to accept feeding and a greater catabolism during the first days of life. Newborns with a high index, on the other hand, have greater deposits as a consequence of glucose coming from the mother stimulating a greater production of fetal insulin and increasing the use of glucose, leading to hypoglycemia. The hypoglycemia of the FT SGA NB with low index may be explained by the limited deposits of these neonates ${ }^{(14)}$.

Sepsis was more associated with low index and the PT NB, probably pointing to the same physiological process. Perinatal infection is the cause of premature labor and the premature newborn is much more subject to infections because of its reduced immunological capacity ${ }^{(15)}$, which would explain this finding.

RDS affects NB younger than 35 weeks. The curves that utilize GA have the power of identifying the risk for this disorder ${ }^{(16)}$. The greater frequency among NB with a low index is due to the fact that in this class there is a greater concentration of PT NB, as was previously described. On the other hand, among NB with low indexI there are also the FT SGA that would have some degree of protection against RDS by pulmonary maturity, favored by stress when this occurs after 32 weeks ${ }^{(17)}$. Kaplan et al. reported that in NB with GA $>36$ weeks, the risk of presenting with RDS may vary from 1 to $39 \%$, according to the surfactant/amniotic fluid (S/Af) ratio. Since this type of test was not carried out among the NB of this sample, one can speculate that the FT SGA NB identified as at risk for RDS might have had a low lecithin/sphingomyelin ratio ${ }^{(18)}$ to explain this finding.

The other respiratory diseases included various conditions that can affect NB of any gestational age or nutritional level, explaining why no association was 
found with the adequacy weight for GA. However, there was an association between lowI and high indices. A prior project, analyzing some of these diseases separately, such as transient tachypnea and congenital pneumonia, showed that they were associated with the NB with a low index ${ }^{(1)}$.

Despite jaundice not having proved associated with any of the classifications, it was noted that PT AGA neonates presented a higher frequency of this disorder than in other groups, possibly due to hepatic immaturity, which would justify the finding ${ }^{(19)}$. In NB with a low index, the association also was not seen, possibly due to the small sample.

A greater frequency of asphyxia would be expected among PT AGA NB with a low index and a FT SGA NB because of the pathophysiological process that involves this disorder. An already compromised fetus does not tolerate the transient hypoxia of labor ${ }^{(20)}$. Prematurity and fetal malnutrition are related to low levels of deposits and therefore, to the impossibility of recovery by means of glycolysis ${ }^{(20,21)}$. Since asphyxia in this paper was defined as first minute Apgar $<7$, covering different degrees of asphyxia, the 5-minute Apgar was not specified. Therefore, moderate or light asphyxia would reflect the NB recovery capacity, which leads to the supposition of exposure to asphyxiating factor for less time ${ }^{(20,21)}$, besides adequate resuscitaton maneuvers, which would mean that the 5-minute Apgar might not indicate abnormalities ${ }^{(22)}$. On the other hand, some reports pointed out that a low Apgar scores during the first minute indicates risk for the NB and is related to greater mortality ${ }^{(23,24)}$.

The fact of having found, in a similar way, an association between frequent NB's diseases both with the weight/length ratio index and with the weight adequacy for gestational age classification, show that the adoption of the index could substitute the classification of the NB according to weight for GA, in evaluating risk for certain neonatal diseases.

Nevertheless, this study shows limiting factors related to the small number of patients in this sample; thus, the generalization of these data may be questioned, which is the reason why we recommend studies with larger samples. Nonetheless, for some populations, due to the difficulty in obtaining the correct GA, it would signify a simple form of foreseeing perinatal risk and subsequently adopting pertinent therapeutic measures.

\section{CONCLUSION}

The weight/length index proved to be associated with frequent diseases of neonates similar to the adequacy weight for gestational age, with the advantage of not being necessary to calculate GA. Since NB weight and length are measured immediately after birth, and the index is obtained merely by dividing one value by the other, it is possible to immediately classify the NB, without the use of tables or graphics.

\section{REFERENCES}

1. Bertagnon JR, de Mattos Segre CA, Dall Colletto GM. Weight-for-length relationship at birth to predict neonatal diseases. São Paulo Med J. 2003;121(4):149-54

2. Bertagnon JR. Relações entre peso e comprimento ao nascer para prognosticar. afecções neonatais [tese]. São Paulo: Instituto de Assistência Médica ao Servidor Público Estadual de São Paulo; 2002.

3. Cole TJ, Henson GL, Tremble JM, Colley NV. Birthweigth for length, ponderal index, body mass index or Benn index? Ann Hum Biol. 1997;24(4):289-98.

4. Fok TF, Hon KL, Ng PC, Wong E, So HK, Lau J, Chow CB, Lee WH; Hong Kong Neonatal Measurements Working Group. Use of anthropometric indices to reveal nutritional status: normative data from 10,226 Chinese neonates. Neonatology. 2009;95(1):23-32.

5. Kramer MS, Olivier M, McLean FH, Willis DM, Usher RH. Impact of intrauterine growth retardation and body proportionality on fetal and neonatal outcome. Pediatrics. 1990;86(5):707-13.

6. Leão JCF, Lira PIC. [Study of body proportionality using Rohrer Ponderal Index and degree of intrauterine growth retardation in full-term neonates]. Cad Saúde Pública. 2003;19(6):1603-10. Portuguese.

7. Ramos JLA. Pequenos para a idade gestacional: gravidade, proporcionalidade e mortalidade. J Pediatr (Rio J). 2005:81 (3):187-8.

8. Segre CA, Bertagnon JR. 0 recém-nascido com restrição de crescimento intra uterino. In: Segre CA, Costa HP, Lippi UG, editores. Perinatologia. Fundamentos e prática. 2a ed.São Paulo: Sarvier;2009.p.188-94.

9. Capurro H, Konichezky S, Fonseca D, Caldeyro-Barcia R. A simplified method for diagnosis of gestational age in the newborn infant. J Pediatr.1978;93(1):120-2.

10. Roselli CA, Segre CA. Avaliação da idade gestacional. Classificação do recémnascido. In: Segre CA,Costa HP, Lippi UG, editores. Perinatologia. Fundamentos e prática. 2a ed.São Paulo: Sarvier;2009. p.440-7.

11. Davidson S, Sokolover N, Erlich A, Litwin A, Linder N, Sirota L. New and improved Israeli reference of birth weight, birth length, and head circumference by gestational age: a hospital-based study. Isr Med Assoc J. 2008; 10(2):130-4.

12. Schlesinger J, Santos PV, Bertagnon JR. Intrauterine growth curve in a low income population in the outskirts of the city of São Paulo. einstein. 2005; $3(4): 255-60$.

13. Bertagnon JR, Armond JE, Rodrigues CL, Jabur VA, Kuraim GA, Novo NF, et al. Birth-weight distribution of Hospital Geral do Grajau population compared to São Paulo city population. einstein. 2010:8(1):1-4.

14. Wilker RE. Hypoglicemia and hyperglicemia. In: Cloherty JP, Eichenwald EC, Stark AR, editores. Manual of neonatal care. 6th ed. Philadelphia: Wolkers Kluwer/ Lippincott Williams \& Wilkins; 2008.p. 540-9.

15. Vedovato $S$, Zanardo V.[Chorioamnionitis and inflammatory disease in the premature newborn infant].Minerva Pediatr. 2010;62(3 Suppl 1):155-6. Italian.

16. Sweet D, Bevilacqua G, Carnielli V, Greisen G, Plavka R, Saugstad OD, et al. European consensus guidelines on the management of neonatal respiratory distress syndrome. J Perinat Med. 2007;35(3):176-86.

17. Sharma P, McKay K, Rosenkrantz TS, Hussain N. Comparisons of mortality and pre-discharge respiratory outcomes in small-for-gestational-age and appropriatefor-gestational-age premature infants. BMC Pediatr. 2004;4:9.

18. Kaplan LA, Chapman JF, Bock JL, Santa Maria E, Clejan S, Huddleston DJ, et al. Prediction of respiratory distress syndrome using the Abbott FLM-II amniotic fluid assay. Clin Chim Acta. 2002;326(1-2):61-8. 
19. Segre CA, Bastos F. Icterícias com aumento da bilirrubina indireta. In: Segre CA, Costa HP, Lippi UG, editores. Perinatologia. Fundamentos e prática. 2a ed. São Paulo: Sarvier;2009. p. 720-36.

20. Kaijser M, Bonamy AK, Akre 0, Cnattingius S, Granath F, Norman M, et al. Perinatal risk factors for ischemic heart disease: disentangling the roles of birth weight and preterm birth. Circulation. 2008;117(3):405-10.

21. Santos AM. Asfixia perinatal. In:Segre CA, Costa HP, Lippi UG, editores. Perinatologia. Fundamentos e prática. 2a ed. São Paulo: Sarvier; 2009. p. 561-71.
22. Patel D, Piotrowski ZH, Nelson MR, Sabich R. Effectof a statewide neonatal resuscitation training program on Apgar scores among high-risk neonates in Illinois. Pediatrics. 2001;107(4):648-55.

23. Basu $S$, Rathore P, Bhatia BD. Predictors of mortality in very low birth weight neonates in India. Singapore Med J. 2008;49(7):556-60.

24. Osorno Covarrubias L, Acosta Mass A, Dávila Velázquez J, Gómez García M, Diego Rodríguez N, Echeverría EM. [Neonatal mortality in a regional perinatal hospital in Merida, Yucatan, 1995-2004. II. Analysis of causes and risk factors]. Ginecol Obstet Mex. 2006;74(9):453-61. Spanish. 